\title{
Polypore survey of Finland 4. Phaeolus, Fistulina, Ganoderma and Ischnoderma
}

\author{
TUOMO NIEMELÄ and HEIKKI KOTIRANTA
}

\begin{abstract}
NIEMELÄ, T. \& KOTIRANTA, H. 1986: Polypore survey of Finland 4. Phaeolus, Fistulina, Ganoderma and Ischnoderma. - Karstenia 26: 57-64.

The Finnish distribution is mapped for five polypore species. Phaeolus schweinitzii (Fr.) Pat. has rare occurrences almost throughout the country, mainly on Larix sibirica and Pinus sylvestris. Fistulina hepatica Schaeff.: Fr. is strictly Hemiboreal, growing on Quercus robur and (one record) Castanea sativa. Ganoderma lipsiense (Batsch) Atk. ( $G$. applanatum) is a polyphagous saproparasite, common in the Hemiboreal and Southern boreal zones and rarer in the Middle boreal zone. Ganoderma lucidum (Curt.: Fr.) Karst. favours large stumps of Alnus glutinosa and has rare occurrences in the Hemiboreal and Southern boreal zones only. Ischnoderma benzoinum (Wahl.) Karst. is distributed over the whole of Finland, but is common only in the south. It grows mostly on Picea abies, less often on Pinus sylvestris, and exceptionally on a few other hosts. None of these fungi cause notable economic losses as decaying agents.
\end{abstract}

Tuomo Niemelä and Heikki Kotiranta, Department of Botany, University of Helsinki, Unioninkatu 44, SF-00170 Helsinki, Finland

\section{Foreword}

In two earlier papers of this series (Niemelä \& Kotiranta 1982, 1983) we presented maps of the poroid Hymenochaetales. The systematic position of Phaeolus has varied from time to time. Externally and microscopically the genus resembles Coltricia, Onnia and other monomitic, stipitate Hymenochaetales, but it has often been excluded from that order because of the fact that it causes brown-rot. However, $P$. schweinitzii does not react to the gum guaiac, gallic acid and tannic acid tests as a true brown-rot fungus (Gilbertson et al. 1975), and its fruit bodies have the triterpene content which is characteristic of the white-rot species (Yokoyama et al. 1975). So P. schweinitzil is at least untypical as a brown-rot fungus. Further evidence has been found that connects Phaeolus with the Hymenochaetales, the most important being that it has the same characteristic styrylpyrone pigment composition (Fiasson 1982). Phaeolus seems to be especially close to Coltricia: both have normal multiperforate parenthesomes in their hyphal septa
(Moore 1980), while Onnia, Inonotus, etc. have nonperforate parenthesomes, which are generally considered to be restricted to the Heterobasidiomycetidae (see a summary by Khan \& Kimbrough 1982). In view of all this evidence, Fiasson and Niemelä (1984) proposed the inclusion of Phaeolus in the Hymenochaetales and divided the order into two suborders, the Phaeolinae for Phaeolus and Coltricia, and the Hymenochaetinae for all the other genera (Hymenochaete, Onnia, Inonotus, Phellinus s.lat., etc.).

The other genera in this paper have rather isolated positions in the system of the pore fungi. Within each genus, all the species are treated which are known to occur in Finland. This means, for example, that $\mathrm{Ga}$ noderma adspersum (Schulz) Donk, G. carnosum Pat., G. pfeifferi Pat. and G. resinaceum Pat. are omitted, because they are not found in the country, and Ischnoderma is represented by $I$. benzoinum only.

For the general terms used in this survey, the material included, etc., the reader is referred to the Introduction to this series (Niemelä 1982). 
Phaeolus schweinitzii (Fr.) Pat.

$\begin{array}{lrrrrr} & \begin{array}{c}\text { Whole of } \\ \text { Finland }\end{array} & \text { A-U } & \text { EK-PK } & \text { KP-PP } & \text { KemL } \\ \text { Larix } & 64.2 & 66.7 & 60.0 & 100 & - \\ \text { - sibirica } & 17.9 & & & & \\ \text { - decidua } & 9.4 & & & & \\ \text { - gmelinii (dahurica) } & + & & & & \\ \text { Pinus sylvestris } & 31.1 & 28.0 & 35.6 & - & + \\ \text { Picea } & 2.8 & 3.5 & + & - & - \\ \text { - abies } & 1.9 & & & & \\ \text { - engelmannii } & + & & & & \\ \text { Abies } & 1.4 & + & + & - & - \\ \text { - sibirica } & + & & & & \\ \text { Pseudotsuga menziesii } & + & + & - & - & - \\ \text { Quercus robur } & + & + & - & - & - \\ \text { Host not indicated } & 34 & & & & \\ \text { Specimens examined } & 142 & 84 & 54 & 3 & 1 \\ & & & & & \end{array}$

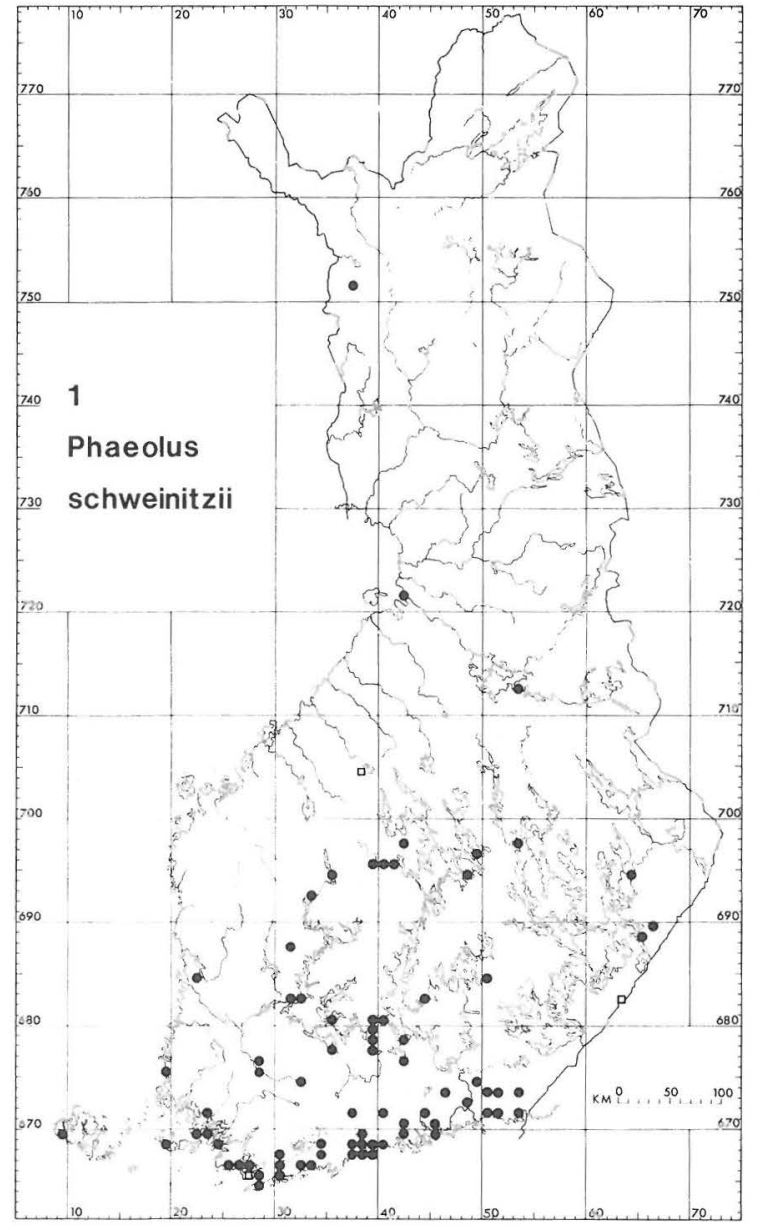

Fig. 1. Phaeolus schweinitzii in Finland. Open squares indicate literature records.
P. schweinitzii is distributed through most of Finland, but it becomes rarer towards the north. It is scattered in the Hemiboreal zone and the southern Lake District, emerging regularly in its old sites, but without being common anywhere. It is rare elsewhere in the Southern boreal zone, and very rare in the Middle and Northern boreal areas.

Almost two-thirds of the collections derive from Larix (mostly $L$. sibirica), which is an exotic tree genus in Finland. Most of the others originate from Pinus sylvestris. These proportions are interesting, because Pinus is regarded as the main host genus for the species all around Europe. In Finland a gradual shift is evident from one host to another (compare the columns A-U and EK-PK). Along the southern coast, the fungus is most often found around aged larchtrees in old manor and town parks. In the Lake District and farther north, the characteristic sites are around the largest pines, 200-500 years old, mainly in virgin forests or otherwise protected areas. The other hosts are quite exceptional. The find on Quercus robur was made by Mr Pentti Alanko, Head Gardener of the University Botanical Garden, Helsinki, and the host determination is thus reliable.

Koskinen (1955) reported P. schweinitzii from two localities in central Finland, Schulmann $(1955,1957$, $1960,1963)$ published several finds from southern and eastern Finland, and Laine (1967) reported a collection from the Åland archipelago.

The fruit bodies grow mainly on the ground around the host trees. They were found more rarely on the bases of dead trees, standing or recently fallen, at a height of $0-2 \mathrm{~m}$. Fruit bodies were collected once in the crown of a living pine, at a height of $4 \mathrm{~m}$. The persistence of the occurrences has been followed, e.g., in the Botanical Garden of the University of Helsinki, where observations have been made and specimens collected repeatedly from the year 1892 to the present 
(Niemelä \& Erkkilä 1983). The species is a parasite, causing butt- and root-rot. Due to its rarity, it is of minor economic importance in Finland and the decay proceeds so slowly that the damage to park trees is small. The main harm is caused by its tendency to affect the oldest trees, saved and protected as natural monuments.

In the adjacent areas, the species was mapped in Norway, Denmark and Sweden by Ryman and Holmåsen (1984). Parmasto (1959) gave records from the Estonian S.S.R., on Larix, Pinus sylvestris and Picea abies, and Šubin and Krutov (1979) reported it as rare in southern Soviet Karelia, on the same hosts. The northernmost record is that of Ryvarden (1971) from the Goskamark Forest Reserve, Finnmark, on the northern coast of Norway. The range of the species in Europe extends south to the Mediterranean countries. Ryvarden (1976) reported it from the Canary Islands.

Occurrence of P. schweinitzii with Buchwaldoboletus lignicola (Kallenb.) Pilát has been reported in Czechoslovakia, Poland and Great Britain by Kuthan and Šedlivý (1971), Szczepka (1981), Lipka (1985) and Brown (1985). No such association has been observed in Finland. B. lignicola has been reported once from southern Finland (Kallio \& Heikkilä 1978) and $P$. schweinitzii has been collected several times in the same area (Grid $27^{\circ} \mathrm{E} 666: 32$, Inkoo: Fagervik), but no cross-references exist on the herbarium labels.

Fistulina hepatica Schaeff.: Fr.

$$
\text { A-U }
$$

$\begin{array}{lr}\text { Quercus } & 97.4 \\ \text { - robur } & 30.8 \\ \text { Castanea sativa } & + \\ \text { Host not indicated } & 8 \\ \text { Specimens examined } & 47\end{array}$

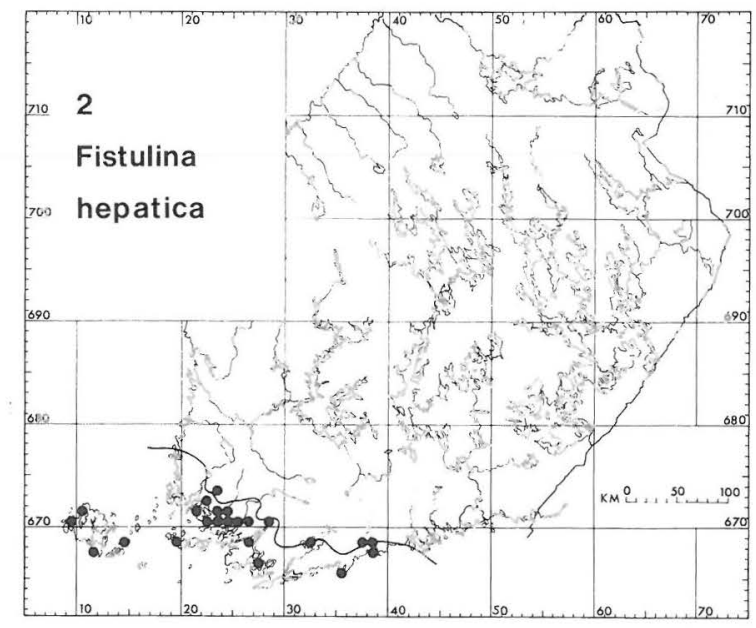

Fig. 2. Fistulina hepatica in Finland. The thin line is the northern limit of the Hemiboreal zone.

Kallio (1963) and Kallio \& Kankainen (1967) gave ecological notes and listed old collections from the surroundings of Turku, and Laine (1967) listed the finds from Aland. Å strictly southern distribution is also evident from the map from Norway (Eckblad \& Gulden 1974). Lange (1974) presented the distribution in Europe (excl. western Mediterranea and the U.S.S.R.): the species seems to be rarer in the most oceanic western areas.

Ganoderma lipsiense (Batsch) Atk. (G. applanatum (Pers.) S.F. Gray)

$\begin{array}{lrrrr} & \begin{array}{r}\text { Whole of } \\ \text { Finland }\end{array} & \text { A-U } & \text { EK-PK } & \text { KP-PP } \\ \text { Betula } & 35.0 & 23.0 & 48.8 & 21.4 \\ \text { - pubescens } & 2.7 & & & \\ \text { - pendula } & 1.6 & & & \\ \text { Populus } & 25.7 & 13.9 & 33.0 & 64.3 \\ \text { - tremula } & 24.9 & & & \\ \text { - X berolinensis } & + & & & \\ \text { - suaveolens } \mathrm{f} & & & & \\ \quad \text { fastigiata } & + & & & \\ \text { Alnus } & 6.6 & 10.7 & 3.3 & - \\ \text { - glutinosa } & 5.0 & & & \\ \text { Quercus robur } & 6.6 & 13.1 & + & - \\ \text { Salix } & 5.4 & 6.5 & 4.1 & + \\ \text { - caprea } & 3.5 & & & \\ \text { - alba } & + & & & \\ \text { - daphnoides } & + & & & \\ \text { - fragilis } & + & & & \\ \text { - pentandra } & + & & & \\ \text { Picea abies } & 3.1 & 4.9 & + & + \\ \text { Tilia } & 3.1 & 6.5 & - & - \\ \text { - neglecta } & + & & & \\ \text { - X vulgaris } & + & & & \\ & & & & \end{array}$




\section{Acer}

- platanoides

- pseudoplatanus

Fraxinus excelsior

Ulmus

- glabra

Fagus sylvatica

Aesculus

Pinus sylvestris

Prunus cerasus

Sorbus aucuparia

Laburnum alpinum

Malus

Syringa

Host not indicated

Specimens

examined

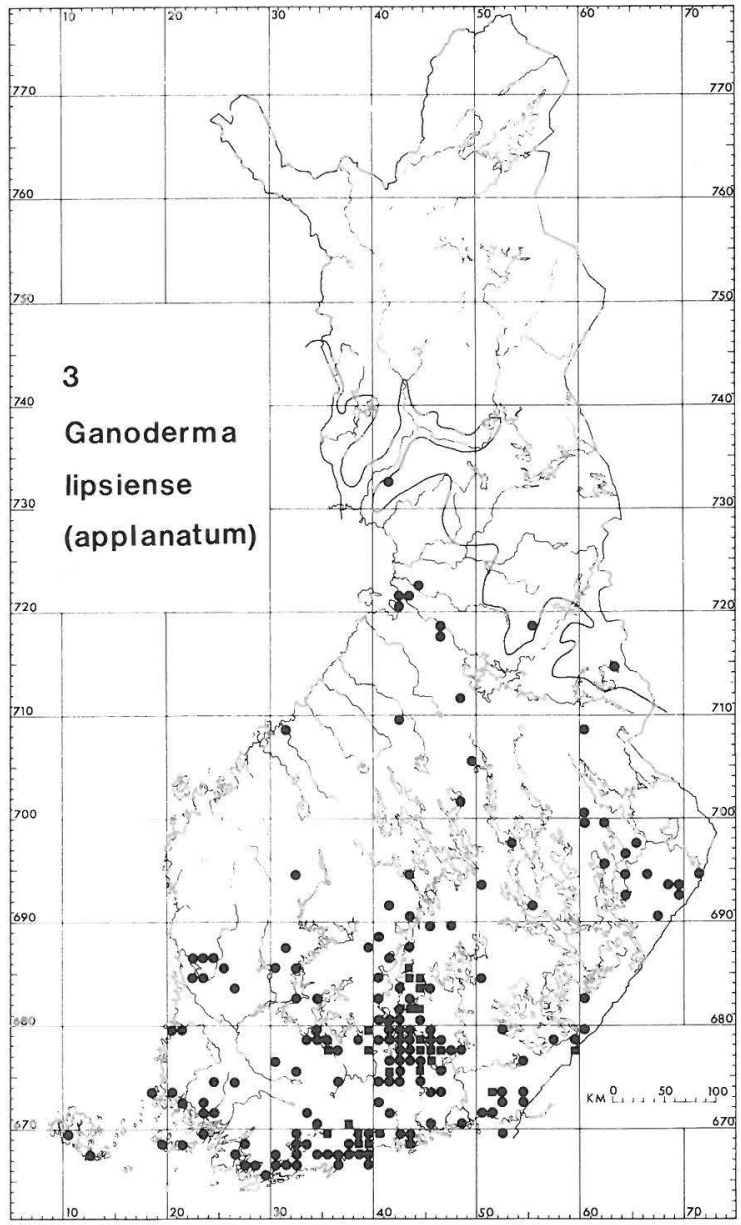

Fig. 3. Ganoderma lipsiense ( $G$. applanatum) in Finland. Black squares indicate Agathomyia wankowiczi galls in the fruit bodies; the thin line is the northern limit of the Middle boreal zone.
The species is common in the Hemiboreal and Southern boreal zones, and scattered to rare in the Middle boreal zone. It reaches the southern limit of the Northern boreal zone, but does not extend farther north. The southerly distribution can be attributed to climatic factors: suitable hosts for $G$. lipsiense occur in the whole of Finland. The accumulation of dots in the southern Lake District is mainly due to Mr Veli - Haikonen, Lic. Phil., who has kindly contributed to - our mapping by systematically gathering records in - the surroundings of the Lahti town. We are grateful - to him - although his activity creates imbalance in - our maps. That, of course, is the fault of others, not - his.

$G$. lipsiense is often considered a saprophyte of aspen, but our list shows that this is the case only in the extreme north; birches are the dominant hosts in the main distributional area. The general spectrum is remarkably wide and consists of many exotic tree species. Fagus sylvatica does not occur in the wild in Finland, and so the host list is very different from that in Central and South Europe (e.g. Kotlaba 1984, Tortic 1985). Conifers serve as hosts only exceptionally.

$G$. lipsiense is sometimes found in natural deciduous or mixed forests, but favours at least slight human influence. It often occurs in the surroundings of rural settlements, in pastured forests, etc., growing especially on large, man-made stumps of birch and aspen. It is less often found on fallen trunks. Another characteristic type of environment is an old town park, where the fungus often grows at the bases of planted, living trees, the fruit bodies emerging just above the ground and remaining as deformed nodulous agglomerations. Their deformation is caused by disturbing grasses and by frequent bruising during the cutting of the lawn. When these trees are cut down, the species colonizes the stumps. $G$. lipsiense is certainly saproparasitic in more natural environments as well, although the fruit bodies emerge only at a later stage. In favourable sites, on large enough stumps, $G$. lipsiense may produce the biggest fruit bodies in the Finnish polypore flora. Conks exceeding the width of one metre are rare but not exceptional.

The species causes some harm by decaying old deciduous trees, especially in parks. Maps have been published by Eckblad and Gulden (1974) from Norway, Ryman and Holmåsen (1984) from Sweden, and Petersen (1983) from Denmark. Lange (1974) has mapped the total distribution in Europe. The species seems to become rarer towards the southwest: Melo (1986) did not find it in Portugal, where it is replaced by $G$. adspersum (Schulz.) Donk ( $G$. australe (Fr.) Pat.).

The hymenophore often bears galls of insect larvae, attributed to Agathomyia wankowiczi Schnabl (Eis- 
felder \& Herschel 1966, Lohwag 1971). The Finnish observations are indicated in the map. Along the southern coast (A-U), the galls are found in $1.9 \%$ of all fruit bodies; in the Lake District (EK-PK) they occupy $11.8 \%$ of the fruit bodies, but they were not found in the marginal northern area (KP-PP). Adult A. wankowiczi has not been reported from Finland (Kotiranta \& Niemelä 1981), but the larvae in the galls closely resemble those illustrated by Eisfelder and Herschel (1966).

Herbarium records give an impression that the insect is becoming commoner. It was first recorded in 1971 in Vihti, SW Finland. The next single records were made in 1978 (Orimattila) and 1979 (Luhanka), in southern Lake District. In 1981 four records were detected (Jaala, Sysmä, Vehkalahti) in the inner Lake District and the southeastern border. Ten specimens have been preserved in 1982 (additional localities Hattula, Heinola, Iitti, Nastola, Tuusula, Vantaa). Fewer records have been preserved during the recent years (additional finds from Hartola, Helsinki, Lammi, Nurmijärvi), but our field notes show the galls to be now found almost invariably in southern Finland. They show no preference to any particular host tree species.

Ganoderma adspersum is externally very similar to $G$. lipsiense, but the two are easily separated microscopically by their different spore sizes (Kotlaba \& Pouzar 1971). We checked all southern Finnish specimens liable to misidentification, but no $G$. adspersum was found. Petersen (1983) reports it from Denmark and Watling (1984) from Scotland.

Ganoderma lucidum (Curt.: Fr.) Karst.

Whole of A-U EK-PK KP Finland

$\begin{array}{lrrrr}\text { Alnus } & 50.0 & 59.5 & - & 75.0 \\ \text { - glutinosa } & 44.0 & & & \\ \text { Betula } & 18.0 & 13.5 & 44.4 & - \\ \text { Picea abies } & 18.0 & 13.5 & 44.4 & - \\ \text { Quercus robur } & 6.0 & 8.1 & - & - \\ \text { Pinus sylvestris } & 4.0 & + & - & + \\ \text { Abies } & + & - & + & - \\ \text { Larix } & + & + & - & - \\ \text { Host not indicated } & 29 & & & \\ \text { Specimens examined } & 79 & 61 & 14 & 4\end{array}$

The distribution of G. lucidum in Finland is restricted to the Hemiboreal and Southern boreal zones. The species is rare or very rare, and found regularly only in a few extremely favourable sites. This striking polypore is easily observed and collected, and so the scarcity of the dots on the map reflects the true situation. The observations are slightly concentrated in the coastal and western parts of the

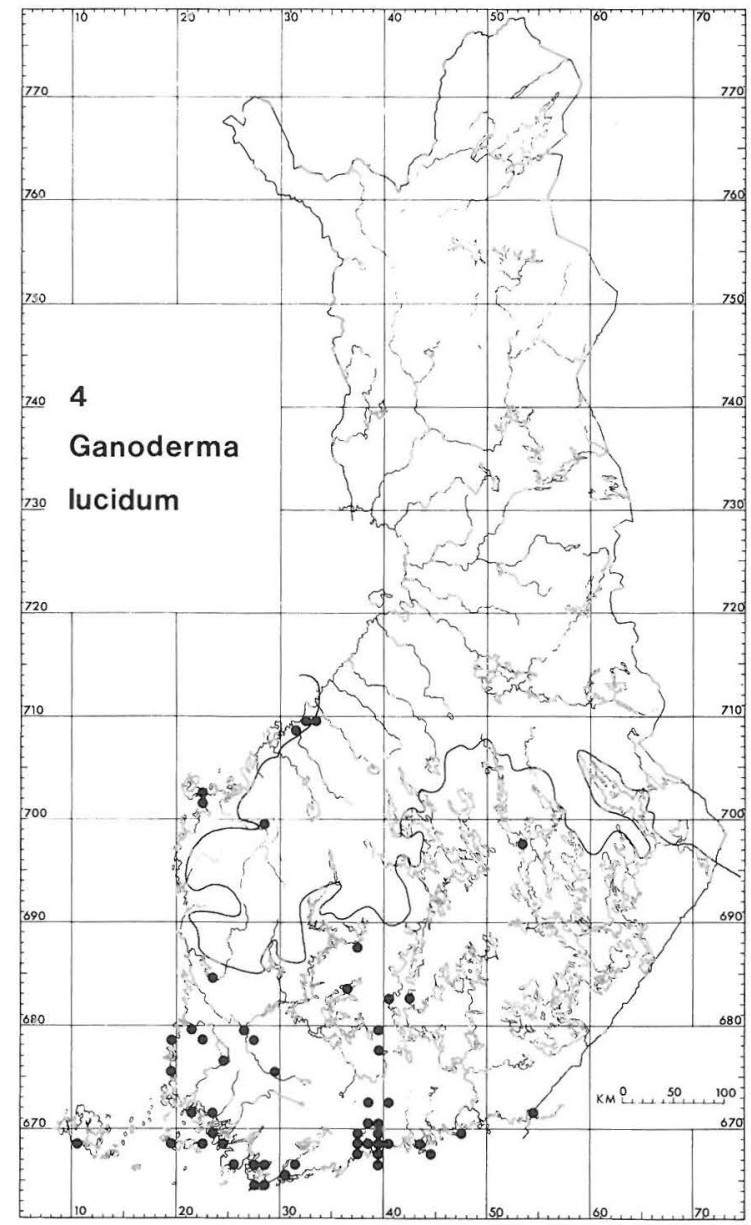

Fig. 4. Ganoderma lucidum in Finland. The thin line is the northern limit of the Southern boreal zone.

range, which may indicate preference of a somewhat oceanic climate.

The species clearly favours hardwoods. The high percentage for Alnus glutinosa has been achieved in a few localities with abundant occurrences. A characteristic example is U: Tammisaari, Ramsholm recreational area (Grid $27^{\circ} \mathrm{E}$ 665:30), where G. lucidum grows on several large alder stumps in a luxuriant seashore grass-herb forest. This is perhaps the most representative permanent occurrence of the species in Finland. The finds on Betula are more scattered and made mostly only once per locality.

C. lucidum has been collected quite often on conifers, too. In this connection we kept a special lookout for G. carnosum Pat. (G. atkinsonii Jahn, Kotl. \& Pouz.), which is a similar species, but separated by its darker colour and wider spores (average spore width over $7.4 \mu \mathrm{m}$ ). G. carnosum is distributed in Central 
and South Europe and southern Great Britain (Jahn, Kotlaba \& Pouzar 1980, Kotląba 1984), growing mainly on Abies alba in lower montane forests. $G$. carnosum does not occur in North Europe, not even in Denmark (Petersen 1983).

The distribution of G. lucidum roughly follows the northern limit of the Southern boreal zone in Sweden and Norway as well (Ryman \& Holmåsen 1984). The northernmost finds in Sweden were made in the surroundings of Sundsvall (Tedebrand \& Strid 1981), and so the species extends about $200 \mathrm{~km}$ farther north on the Finnish side of the Gulf of Bothnia. Parmasto (1959) mapped G. lucidum in the Estonian S.S.R. and
Petersen (1983) in Denmark. The total range of the species is impossible to delimit, because it is a member of a very difficult complex with many closely related species.

G. lucidum is found most often in moist, shady grass-herb forests, growing on large stumps of alder or birch, which have mostly reached the final stage of decomposition. Other typical growth sites are moist lakeside forests, which may be waterlogged in spring, and dense spruce-hardwood swamps, where fruit bodies are sometimes found on fallen spruce or birch trunks. The species is economically harmless in Finland.

\section{Ischnoderma benzoinum (Wahl.) Karst.}

$\begin{array}{lrrrr}\begin{array}{l}\text { Whole of } \\ \text { Finland }\end{array} & \text { A-U EK-PK } & \text { KP-PP Ks-InL } \\ & & & & \\ 74.7 & 67.7 & 76.5 & 100.0 & 88.9 \\ 23.0 & 28.3 & 22.4 & - & + \\ 23.0 & & & & \\ + & & & & \\ 1.6 & 3.1 & - & - & - \\ 0.8 & & & & - \\ + & - & + & - & - \\ + & + & - & - & - \\ 85 & & & & \\ 342 & 169 & 135 & 26 & 12\end{array}$

I. benzoinum is found all over Finland. It is fairly common in southern Finland, but becomes scattered or rare in the northern Lake District and farther north. The records in western Lapland reach the distribution limit of spruce; the extreme north-eastern record (Grid $27^{\circ} \mathrm{E} 762: 52$ ) is from pine. The species seems to be rather indifferent to the oceanity of the climate.

Picea abies is the favourable host of I. benzoinum in the whole country, and almost the only host in the northern half. Pinus sylvestris is also a fairly common host in southern Finland. The other hosts are represented in a few collections, and hardwoods are met with only exceptionally. In Central Europe hardwoods are occupied by an allied species, Ischnoderma resinosum (Fr.) Karst., which is not found in Finland.

I. benzoinum occurs most often in dense and shady spruce forests of fairly rich forest types (the Myrtillus or Oxalis-Myrtillus types). It is found both in virgin forests and in areas influenced by man. The fruit bodies appear on old stumps, which may be rather extensively decayed and are often covered by moss and other epiphytic vegetation; they are found less often on fallen trunks. The economic importance is small, because the decay proceeds very slowly and before it is far advanced the trunks have already been spoiled by other fungi. It may be a weak parasite, but we have no direct evidence of this; all the fruit bodies were found on dead wood.

Ryman and Holmåsen (1984) presented a rough general map of the species in the Nordic countries and the ditribution in Central Sweden was mapped by Strid (1975). These are the only maps we know from northwestern Europe.

Acknowledgements. Financial support from the Emil Aaltonen foundation and Suomen Kulttuurirahasto to Heikki Kotiranta is gratefully acknowledged. Mrs Anna A. Damström, M.A., revised the English of this paper. 


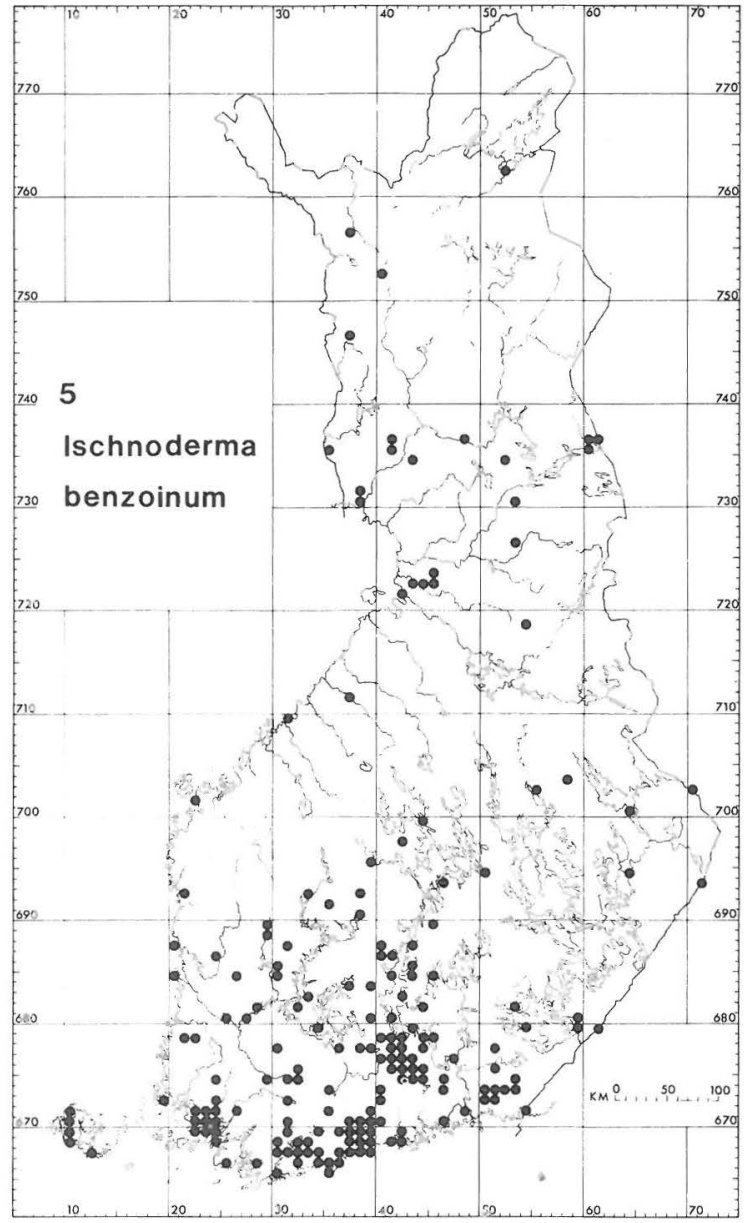

Fig. 5. Ischnoderma benzoinum in Finland.

\section{References}

Brown, R. 1985: Is there an association between Boletus lignicola and Phaeolus schweinitzii? - Bull. Brit. Mycol. Soc. 19:61-63.

Eckblad, F.-E. \& Gulden, G. 1974: Distribution of some macromycetes in Norway. - Norw. J. Bot. 21:285-301.

Eisfelder, I. \& Herschel, K. 1966: Agathomyia wankowiczi Schnabl, die Zitzengallenfliege aus Ganoderma applanatum. - Westfäl. Pilzbriefe 6:5-10.

Fiasson, J.-L. 1982: Distribution of styrylpyrones in the basidiocarps of various Hymenochaetaceae. - Biochem. Syst. Ecol. 10:289-296.

Fiasson, J.-L. \& Niemelä, T. 1984: The Hymenochaetales: a revision of the European poroid taxa. - Karstenia 24:14-28.

Gilbertson, R., Lombard, F. \& Canfield, E. 1975: Gum guaiac in field tests for extracellular phenol oxidases of wood-rotting fungi and other Basidiomycetes. - USDA For. Serv. Res. Pap. FPL 269:1-23.
Jahn, H., Kotlaba, F. \& Pouzar, Z. 1980: Ganoderma atkinsonii Jahn, Kotl. et Pouz., spec. nova, a parallel species to Ganoderma lucidum. - Westfäl. Pilzbriefe 11:97121.

Kallio, P. 1963: Zur Verbreitung einiger in Finnland südlichen Pilze, besonders in der südwestlichen Eichenzone. - Karstenia 6-7:35-76.

Kallio, P. \& Heikkilä, H. 1978: The boletes of Finland 1. Genus Boletus. - Karstenia 18:1-19.

Kallio, P. \& Kankainen, E. 1967: Contributions to the macromycetes in the oak zone of Finland. - Karstenia 8:9-13.

Khan, S. \& Kimbrough, J. 1982: A re-evaluation of the Basidiomycetes based upon septal and basidial structures. -Mycotaxon 15:103-120.

Koskinen, A. 1955: Über die Kryptogamen der Bäume, besonders die Flechten, im Gewässergebiet des Päijänne sowie an den Flüssen Kalajoki, Lestijoki und Pyhäjoki. - PhD Thesis, 176 pp. Helsinki.

Kotiranta, H. \& Niemelä, T. 1981: Composition of the polypore communities of four forest areas in southern Central Finland. - Karstenia 21:31-48.

Kotlaba, F. 1984: Zeměpisné rozšiření a ekologie chorošủ (Polyporales s.1.) v Československu. - 194 pp. Praha.

Kotlaba, F. \& Pouzar, Z. 1971: Ganoderma adspersum (S. Schulz.) Donk, lesklokorka tmavá dvojník lesklokorkorky ploské, G. applanatum (Pers. ex S.F. Gray) Pat. - Česká Mykol. 25:88-102.

Kuthan, J. \& Šedlivý, J. 1971: Pulveroboletus lignicola (Kallenb.) Pil., hřib drevožijný v Československu. - Česká Mykol. 25:135-139.

Laine, L. 1967: Notes on the polypores (Polyporaceae) of Ahvenanmaa. - Karstenia 8:14-20.

Lange, L. 1974: The distribution of macromycetes in Europe. - Dansk Bot. Ark. 30(1):1-105.

Lipka, J. 1985: Weiteres über Buchwaldoboletus lignicola (Kallenbach) Pilát und Phaeolus schweinitzii (Fries) Patouillard. - Z. Mykol. 51:47-50.

Lohwag, K. 1961: Gallenbildung am Flachen Porling. Schweiz. Z. Pilzk. 39:174-175.

Melo, I. 1986: Studies on the Aphyllophorales of Portugal. The genus Ganoderma P. Karst. - Int. J. Mycol. Lichenol. 2:183-204.

Moore, R. 1980: Taxonomic significance of septal ultrastructure in the genus Onnia Karsten (Polyporinae, Hymenochaetaceae). - Bot. Not. 133:169-175.

Niemelä, T. 1982: Polypore survey of Finland 1. Introduction. - Karstenia 22:21-26.

Niemelä, T. \& Erkkilä, R. 1983: Käävät Helsingin yliopiston kasvitieteellisessä puutarhassa. - In: Jalas, J. (ed.), Kasvitiet. Puutarh. Eliömaailmaa 1:83-93. Helsinki.

Niemelä, T. \& Kotiranta, H. 1982: Polypore survey of Finland 2. The genus Phellinus. - Karstenia 22:27-42.

- 1983: Polypore survey of Finland 3. The genera Coltricia, Inonotopsis, Inonotus and Onnia. - Karstenia 23:15-25.

Parmasto, E. 1959: Trutovye griby Estonskoj SSR. - Trudy Bot. Inst. V.L. Komarova AN SSSR II, Spor. Rast. 12:213-273.

Petersen, J. 1983: Lakporesvampene (Ganoderma) i Danmark og Europa. - Svampe 7:1-11.

Ryman, S. \& Holmåsen, I. 1984: Svampar, en fälthandbok. 
$-718 \mathrm{pp}$. Stockholm.

Ryvarden, L. 1971: Studies in the Aphyllophorales of Finnmark, northern Norway. - Rep. Kevo Subarctic Sta. $8: 148-154$.

- 1976: Studies in the Aphyllophorales of the Canary Islands 3 . Some species from the western islands. - Cuad. Bot. Canar. 26-27:29-40.

von Schulmann, O. 1955: Pilzstudien in Finnland. - Karstenia $3: 17-68$.

- 1957: Pilzstudien in Finnland 2. - Karstenia 4:27-61.

- 1960: Zur Kenntnis der Basidiomyceten Finnlands. Karstenia 5:5-99.

- 1963: Zur Kenntnis der Basidiomyzeten Finnlands. Karstenia 6-7:5-34.

Szczepka, M. 1981: Buchwaldoboletus lignicola (Kallenb.) Pil. in Poland. - Fragm. Flor. Geobot. 27:265-274.

Strid, \&. 1975: Wood-inhabiting fungi of alder forests in North-Central Scandinavia 1. Aphyllophorales (Basidiomycetes). - Wahlenbergia 1:1-237.

Subin, V. \& Krutov, V. 1979: Griby Karelii i Murmanskoj oblasti. - 104 pp. Leningrad.

Tedebrand, J.-O. \& Strid, \&. 1981: Lacktickan vid sin nordgräns. - Sveriges Mykol. För. Medlemsblad 2:1516.

Tortić, M. 1985: Distribution of polypores in Yugoslavia 2. Ganodema. - Acta Bot. Croat. 44:59-71.

Watling, R. 1984: Larger fungi around Kindrogan, Perthshire. - Tr. Roy. Soc. Edinburgh 44:237-259.

Yokoyama, A., Natori, S. \& Aoshima, K. 1975: Distribution of tetracyclic triterpenoids of lanostane group and sterols in the higher fungi, especially of the Polyporaceae and related families. - Phytochemistry 14:487-497.

Accepted for publication

on 17 December 1985 